\title{
Detection and Phylogenetic Analysis of Fish Viruses Inhabiting Freshwater Ornamental and Food Fish Species in India: A Survey-Based Study
}

\author{
Vertika Bajpai ${ }^{1}$, Divya Pragyan ${ }^{1}$, Jyotirmaya Mohanty ${ }^{2}$, Pramoda Kumar Sahoo ${ }^{1, *}$
}

\begin{abstract}
${ }^{1}$ National Referral Laboratory for Freshwater Fish Diseases, Fish Health Management Division, ICAR-Central Institute of Freshwater Aquaculture, Kausalyaganga, Bhubaneswar 751002, India.

${ }^{2}$ National Referral Laboratory for Freshwater Fish Diseases, Fish Genetics and Biotechnology Division, ICAR-Central Institute of Freshwater Aquaculture, Kausalyaganga, Bhubaneswar 751002, India.
\end{abstract}

\section{Article History}

Received 18 July 2020

Accepted 23 November 2020

First Online 30 November 2020

\section{Corresponding Author \\ Tel.: +916742465421 \\ E-mail: pksahoo1@hotmail.com}

\section{Keywords}

Freshwater fish

PCR

Phylogeny

Survey

Viruses

\begin{abstract}
Molecular screening of viruses through PCR is a fast detection method and several variants of it have been developed to meet the shortcomings of conventional method. Extensive surveillance is an essential tool to have an estimate of circulating potential viruses in Indian aquatic systems. The present study focuses on standardization of semi-quantitative PCR-based diagnostics for eight freshwater fish viral pathogens and documents number of positive incidences after screening 437 numbers of samples during 2017-2020 for suspected fifteen freshwater finfish viral pathogens. Positive samples of Cyprinid herpes virus-2, carp edema virus and viral nervous necrosis virus from different regions of eastern Indian states viz., Odisha, West Bengal and Assam have given a scope of comparative phylogenetic analysis of strain variability in detail. Nevertheless, the study highlights the importance of rendering protection to native cultured fish by preventing their introduction and further spread on a local or national scale to either known or unknown susceptible fish species available in the region, and emphasize upon strengthening surveillance system.
\end{abstract}

\section{Introduction}

Pathogenic invasion has been an intractable factor for disease occurrence. With the increasing rage of virus outbreaks reported across the Asian countries, an estimate of total positive samples collected and screened for multiple known viruses might bring out ideas to restrict their transmission. Additionally, such records facilitate and enhance maintenance of virus repositories. India, being one of the leading contributors of aquafauna to the world, has been facing economic losses due to diseases in freshwater pisciculture. Potential factors which contribute to it are increase in transboundary movement of ornamental trade, high stocking densities at marketing and transport points, and wide range of prevailing temperature within the boundary causing stress in fish. A number of viruses have been reported in freshwater fishes namely,
CyHV- 3 (Cyprinid herpesvirus-3), EHNV (Epizootic haematopoietic necrosis virus), RSIV (Red sea bream iridovirus), VNNV (Viral nervous necrosis virus), SHRV (Snakehead Rhabdovirus), CyHV-1 (Cyprinid herpesvirus-1), CyHV-2 (Cyprinid herpesvirus-2), SNRV (Snakehead retrovirus), ISAV (Infectious salmon anaemia virus), CCV (Channel catfish virus), VHSV (Viral hemorrhagic septicemia virus), SVCV (Spring viremia of carp virus), IHNV (Infectious hematopoietic necrosis virus), IPNV (Infectious pancreatic necrosis virus), WSIV (White sturgeon iridovirus), TiLV (Tilapia lake virus), CEV (Carp edema virus), LCDV (Lymphocystis disease virus), LMBV (Largemouth bass virus), GCRV (Grass carp reovirus) and megalocyti viruses including ISKNV (Infectious spleen and kidney necrosis virus) (Crane \& Hyatt, 2011; Sahoo \& Goodwin, 2012; Walker \& Winton, 2010). Few viral diseases have been identified in freshwater fishes from India including but not limited to 
CEV (Swaminathan et al., 2016; Pragyan et al., 2019; Sahoo et al., 2020a), ranavirus (George et al., 2015), VNN (Binesh, 2013; Banu et al., 2019), MCV-ISKNV (Anonymous, 2018), TiLV (Behera et al., 2018) and CyHV2 (Sahoo et al., 2016) so far. Virus might act as a natural immunosuppressive agent facilitating the invasion of opportunistic pathogens leading to mass mortalities as noticed in our earlier study with CyHV-2 and CEV (Sahoo et al., 2016, 2020a). Likely cause of evolving viral strains involves gradual change in abiotic factors (Brown et al., 2012). A periodical survey on fish viruses from farmed as well as traded ornamental and food fish can provide significant information on entry or emergence of new pathogens besides presence of endemic ones, and provide alertness for effective management. The potential origin of the new virus can be drawn from phylogenetic study. Over the past few decades, research efforts and new bioinformatics tools have potentially strengthened our knowledge on the diagnosis of viral diseases (Garseth et al., 2019).

The current study focuses on PCR-screening of known freshwater viruses from ornamental fish samples from the farm or retail outlets along with few diseased food fish samples after standardizing diagnostics for few exotic pathogens. Further, all the PCR-positive samples were subjected to sequencing and phylogenetic analysis for understanding evolutionary relationship.

\section{Materials and Methods}

\section{Collection of Fish Samples}

In the present study, 437 numbers of either moribund or apparently sick fish samples (both from ornamental farms or retailer shops and freshwater fish farms) of diverse species (Table 1) were randomly collected from the states of Odisha, West Bengal, and Assam (Figure 1). All the samples were collected from 30 different locations of these three states (13 sites in Odisha, 11 sites in West Bengal, and 6 sites in Assam) during 14 trips spreading over spring, monsoon and winter seasons. These three states serve as the major seed producers and suppliers of freshwater fish, besides the state West Bengal serving as ornamental fish hub (both for seed production, farming and trade) of India trading more than $90 \%$ of ornamental fish via Kolkata port (Shekharan, 2017). The live fishes in oxygenated water in polybags and moribund/freshly dead fishes in the cooling chamber BioT Carrier (Biocision, LLC) were transported to the laboratory. Samples of fish consisted of 6 orders, 8 families and 19 species (Table 1). The live fishes were euthanized using MS-222 (Sigma-Aldrich) and tissue samples (gills, liver, kidney, spleen, and brain) were collected in $100 \%$ ethanol (EMSURE, Merck), RNAlater (Sigma, Life Science, USA), HBSS (Hanks' Balanced Salt Solution with antibiotics) (Sigma-Aldrich, USA) for molecular identification and further investigations.

\section{Standardization of PCRs for Development of Diagnostics for Various Pathogens}

In order to develop positive controls for exotic virus diagnosis, synthetic gene construct strategy was adopted. CyHV-1, GCRV and CCV genes of interest of double stranded gBlock were synthesized corresponding to primer CyHV-1 F1/R1 with 141 bp, GV14S6 F/R with $312 \mathrm{bp}$ and CCV OR 8F/8R with $335 \mathrm{bp}$ as expected amplicon sizes. The gBlocks were diluted with $25 \mu \mathrm{L}$ of nuclease free water to obtain a final concentration of 10 $\mathrm{ng} / \mu \mathrm{L}$. The primer sets were used for amplifying the respective fragments. The primers were used in a final volume of $25 \mu \mathrm{L}$ containing $1 \mu \mathrm{L}$ of total DNA, $1.5 \mu \mathrm{L}$ (10 pmol) of each primer, $0.25 \mu \mathrm{L}$ of Taq DNA polymerase ( 5 $\mathrm{U} / \mu \mathrm{L}), 2.5 \mu \mathrm{L}$ of $10 \mathrm{X}$ Taq buffer $\mathrm{A}, 0.5 \mu \mathrm{L}$ of dNTPs $(2 \mathrm{mM})$ and $\mathrm{ddH}_{2} \mathrm{O}$ to make final volume to $25 \mu \mathrm{L}$. The reaction

Table 1. Detection of viruses in different fish species

\begin{tabular}{|c|c|c|c|}
\hline Order/ Family & Species & $\begin{array}{c}\text { No. of fish } \\
\text { tested }\end{array}$ & $\begin{array}{c}\text { No. of fish } \\
\text { positive }\end{array}$ \\
\hline Cypriniformes/Cyprinidae & Goldfish (Carassius auratus) & 108 & 25 \\
\hline Cypriniformes/Cyprinidae & Koi carp (Cyprinus carpio) & 61 & 17 \\
\hline Cichliformes/Cichlidae & Angelfish (Pterophyllum sp.) & 11 & _ \\
\hline Cyprinodontiformes/Poeciliidae & Molly (Poecilia sphenops) & 20 & _ \\
\hline Siluriformes/ Clariidae & Catfish (Clarias magur) & 6 & _ \\
\hline Cypriniformes/Cyprinidae & Rainbow shark (Epalzeorhynchos frenatum) & 10 & _ \\
\hline Anabantiformes/Osphronemidae & Three spot gourami (Trichopodus trichopterus) & 15 & - \\
\hline Cichliformes/Cichlidae & Oscar (Astronotus ocellatus) & 4 & _ \\
\hline Cypriniformes/Cyprinidae & Tiger barb (Puntrigus tetrazona) & 8 & - \\
\hline Cypriniformes/Botiidae & Tiger loach (Chromobotia macracanthus) & 8 & - \\
\hline Cypriniformes/Cyprinidae & Grass carp (Ctenopharyngodon idella) & 2 & _ \\
\hline Cypriniformes/Cyprinidae & Puntius sp. & 8 & _- \\
\hline Cypriniformes/Cyprinidae & Black carp (Mylopharyngodon piceus) & 2 & - \\
\hline Cypriniformes/Cyprinidae & Rohu (Labeo rohita), & 14 & - \\
\hline Cypriniformes/Cyprinidae & Catla (Catla catla) & 10 & - \\
\hline Cypriniformes/Cyprinidae & Mrigal (Cirrhinus cirrhosus) & 2 & - \\
\hline Cichliformes/Cichlidae & Tilapia (Oreochromis mossambicus) & 15 & - \\
\hline Anabantiformes/ Channidae & Channa striata & 41 & - \\
\hline Perciformes/Latidae & Asian seabass (Lates calcarifer) & 67 & 12 \\
\hline
\end{tabular}


mix was subjected to 30-35 temperature cycles (30s at $94^{\circ} \mathrm{C}, 30 \mathrm{~s}$ at respective annealing temperatures and 1 min at $72^{\circ} \mathrm{C}$ ) after an initial denaturing step (15 min at $95^{\circ} \mathrm{C}$ ) followed by a final extension step of $7 \mathrm{~min}$ at $72^{\circ} \mathrm{C}$ in a Veriti thermal cycler (Applied Biosystem). Then the amplicons were checked in $1.0 \%$ agarose gel. Similarly, positive controls for RSIV, CyHV-2, VHSV, VNNV, and MCV corresponding to primers RSIV F/R (563 bp), CyHV2 Hel F/R (366 bp), VHSV F/R (505 bp), BNV UF2/UR2 (420 bp), and C1073 /C1074 (167 bp), respectively were PCR amplified. The details of the PCR conditions are given in Table 2. The PCR products of all these eleven viruses were purified using PureLink Quick Gel extraction kit (Invitrogen, Carlsbad, CA) followed by Tvector ligation and cloning into Escherichia coli $\mathrm{DH} 5 \alpha$ using InsTAclone PCR Cloning Kit (Thermo Scientific, USA) according to manufacturer's instructions. Positive clones were outsourced for sequencing for confirmation (Agri Genome Labs Pvt Ltd, Kochi, India). Copy number of main stock plasmid for every single virus was calculated (Ke et al., 2006) and ten (ten-fold) dilutions were used for semi quantitative PCR standardization after spiking with equal amount of control fish DNA/cDNA. The sensitivities of different PCRs for these eleven different viruses were determined using semiquantitative PCR. The diagnostics available in our laboratory earlier or published elsewhere for three other viruses namely, SVCV, CEV (Sahoo et al., 2020a, b) and TiLV (Eygnor et al., 2014) were also utilized in this study for screening purposes. Further, the procedures laid down LCDV (Kitamura et al., 2006), WDSV (Zhang et al., 1996) laid down for and SHRV (Phelan et al., 2005) diagnosis are being followed as such for screening.

\section{DNA Isolation and PCR Amplification}

All tissues (gills, kidney, spleen, liver and brain) collected from live and moribund fishes were pooled individually and processed for total genomic DNA isolation. Tissue samples (approximately $100 \mathrm{mg}$ ) were treated with proteinase $\mathrm{K}$ in lysis buffer $(50 \mathrm{mM}$ Tris $\mathrm{HCl}$, $100 \mathrm{mM} \mathrm{NaCl}, 100 \mathrm{mM}$ EDTA and 1\% (w/v) SDS pH 8.0) and extraction was performed using phenol/chloroform/isoamyl alcohol, followed by ethanol precipitation. Extracted DNA was diluted in TE (50 mM Tris $\mathrm{HCl}, 1 \mathrm{mM}$ EDTA pH 7.5). The concentration and purity of DNA was measured at $260 \mathrm{~nm}$ and $280 \mathrm{~nm}$ using NanoDrop ND1000 spectrophotometer

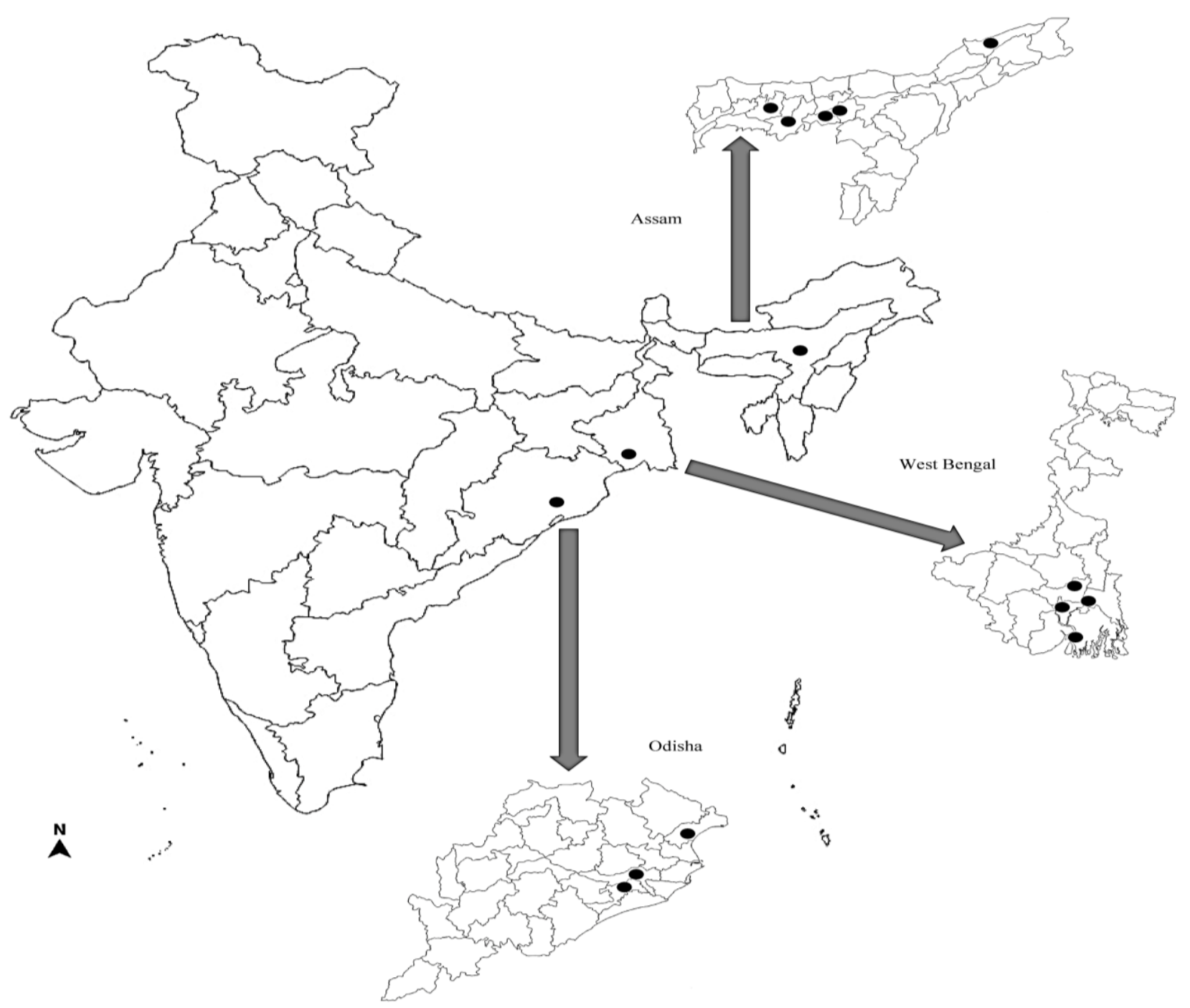

Figure 1. Map showing the geographical locations of sample collection in the states of Odisha, West Bengal and Assam in India. 
(NanoDrop Technologies Inc., USA). Samples were stored at $-20^{\circ} \mathrm{C}$ for further analysis. PCR was performed for suspected fish viral pathogens depending on host specificity using published oligonucleotide primers (Table 2) for seven freshwater finfish DNA viruses using earlier described protocol.

Table 2. List of the primers used in this study with expected size of amplicons and PCR conditions

\begin{tabular}{|c|c|c|c|c|c|c|c|}
\hline $\begin{array}{l}\text { SI } \\
\text { No }\end{array}$ & Viruses & Primer name & Oligonucleotide sequence $\left(5^{\prime}-3^{\prime}\right)$ & $\begin{array}{l}\text { Amplicon } \\
\text { size (bp) }\end{array}$ & $\begin{array}{l}\text { Target } \\
\text { gene }\end{array}$ & $\mathrm{Ta}$ & Reference \\
\hline \multirow[t]{2}{*}{1} & \multirow[t]{2}{*}{ CyHV-1 } & CyHV-1 F1 & CCACAAAACTGGGAGTATGTG & \multirow[t]{2}{*}{141} & \multirow{2}{*}{$\begin{array}{l}\text { Thymidin } \\
\text { e kinase }\end{array}$} & \multirow[t]{2}{*}{$59^{\circ} \mathrm{C}$} & \multirow{2}{*}{$\begin{array}{l}\text { Viadanna et al., } \\
2017\end{array}$} \\
\hline & & CyHV-1 R1 & TGTAGGCTTCTGTTCCACC & & & & \\
\hline \multirow[t]{2}{*}{2} & \multirow[t]{2}{*}{ CyHV-2 } & CyHV-2 Hel F & GGACTTGCGAAGAGTTTGATTTCTAC & \multirow[t]{2}{*}{366} & \multirow[t]{2}{*}{ Helicase } & \multirow[t]{2}{*}{$60^{\circ} \mathrm{C}$} & \multirow{2}{*}{$\begin{array}{l}\text { Waltzek et al., } \\
2009\end{array}$} \\
\hline & & CyHV-2 Hel R & CCATAGTCACCATCGTCTCATC & & & & \\
\hline \multirow[t]{2}{*}{3} & \multirow[t]{2}{*}{ RSIV } & RSIV F2 & TACAACATGCTCCGCCAAGA & \multirow[t]{2}{*}{563} & \multirow{2}{*}{$\begin{array}{l}\text { Pst I } \\
\text { fragment }\end{array}$} & \multirow[t]{2}{*}{$55^{\circ} \mathrm{C}$} & \multirow{2}{*}{$\begin{array}{l}\text { Kurita et al., } \\
1998\end{array}$} \\
\hline & & RSIV R2 & GCGTTAAAGTAGTGAGGGCA & & & & \\
\hline \multirow[t]{8}{*}{4} & $\mathrm{MCV}$ & C1105 & GGGTTCATCGACATCTCCGCG & 430 & Major & $55^{\circ} \mathrm{C}$ & Rimmer et al., \\
\hline & & C1106 & AGGTCGCTGCGCATGCCAATC & & Capsid & & 2012 \\
\hline & & C1073 & AATGCCGTGACCTACTTTGC & 167 & protein & & \\
\hline & & C1074 & GATCTTAACACGCAGCCACA & & (MCP) & & \\
\hline & & MCP-uni322-F3 & AGGTGTCGGTGTCATTAACGACCTG & 777 & Major & $57^{\circ} \mathrm{C}$ & Kurita and \\
\hline & & $\begin{array}{l}\text { MCP-uni1108- } \\
\text { R8 }\end{array}$ & TCTCAGGCATGCTGGGCGCAAAG & & $\begin{array}{l}\text { Capsid } \\
\text { protein }\end{array}$ & & Nakajima, 2012 \\
\hline & & $\begin{array}{l}\text { MCP-specl465- } \\
\text { F3 }\end{array}$ & GGTGGCCGGCATCACCAACGGC & 415 & (MCP) & $58^{\circ} \mathrm{C}$ & \\
\hline & & $\begin{array}{l}\text { MCP-specl879- } \\
\text { R3 }\end{array}$ & CACGGGGTGACTGAACCTG & & & & \\
\hline 5 & $\mathrm{CCV}$ & CCV OR $8 \mathrm{~F}$ & ACGTGTATCACGGTCTCACT & 335 & ORF 8 & $55^{\circ} \mathrm{C}$ & Gray et al., \\
\hline & & CCV OR $8 \mathrm{~F}$ & TTCGAGAATCCGGGTCTCTGT & & & & 1999 \\
\hline 6 & CEV & CEV For B & ATGGAGTATCCAAAGTACTTAG & 528 & Partial 4a & $55^{\circ} \mathrm{C}$ & Matras et al., \\
\hline & & CEV Rev J & СTCTTCACTATTGTGACTTTG & & & & 2017 \\
\hline & & CEV For B-int & GTTATCAATGAAATTTGTGTATTG & 478 & & & \\
\hline & & CEV Rev J-int & TAGCAAAGTACTACCTCATCC & & & & \\
\hline & & CEV F1 & GCTGTTGCAACCATTTGAGA & 548 & 5'UTR ( & $60^{\circ} \mathrm{C}$ & Oyamatsu et \\
\hline & & CEV R1 & TGCAGGTTGCTCCTAATCCT & & Untransla & & al., , 1997 \\
\hline & & CEV F1 & GCTGTTGCAACCATTTGAGA & 481 & & & \\
\hline & & CEV R2 & TGCAAGTTATTTCGATGCCA & & region) & & \\
\hline & & CEV F2 & GCTGCTGCACTTTTAGGAGG & 248 & & & \\
\hline & & CEV R1 & TGCAGGTTGCTCCTAATCCT & & & & \\
\hline 7 & LCDV & LCDVs F & YTGGTTCAGTAAATTACCRG & 609 & ORF-1 of & $60^{\circ} \mathrm{C}$ & Kitamura et \\
\hline & & LCDVs R & GTAATCCATACTTGHACRTC & & $\mathrm{K} 2$ region & & al., 2006 \\
\hline & & SP1 F & CAAGGTAGACCACATGTATATG & 1130 & & $55^{\circ} \mathrm{C}$ & Jeong et al., \\
\hline & & SP1 R & GTCATGTTGCATGTATATG & & & & 2008 \\
\hline & & SP2 F & GTGTGGATGACATAAGTC & 531 & & & \\
\hline & & SP2 R & CACACTAACACACTACG & & & & \\
\hline 8 & SVCV & SVCV $1 F$ & TCTTGGAGCCAAATAGCTCARRTC & 714 & Glycoprot & $55^{\circ} \mathrm{C}$ & Enkeleda and \\
\hline & & SVCV $1 R$ & $\begin{array}{l}\text { AGATGGTATGGACCCCAATACATHCA } \\
\text { NCAY }\end{array}$ & & ein & & Spase, 2014 \\
\hline 9 & GCRV & GV14S6F & ACGTGCGATTGGAAGAGCTT & 312 & M 6 & $58^{\circ} \mathrm{C}$ & Jiang, 2009 \\
\hline & & GV14S6R & AGTTCTCAAAGCTGAGACAG & & segment & & \\
\hline 10 & SHRV & SHRV N-G F & ATTTATCCGCTGGAGAGGGATTGG & 829 & Nucleoca & $55^{\circ} \mathrm{C}$ & Phelan et al., \\
\hline & & SHRV N-G R & GTTGAGCCCATAGGCCTTGAAGTA & & psid & & 2005 \\
\hline 11 & SnRV & SnRV gag-pol F & CAGATCACTGATCGATGC & 284 & Nucleoca & $58^{\circ} \mathrm{C}$ & Eygnor et al., \\
\hline & & SnRV gag-pol R & GTCTGAAAGGTAAGGTGG & & psid & & 2014 \\
\hline 12 & WDSV & Retro GAG-A1 & TCTTACAGCTTGCGATGC & 1389 & Nucleoca & $50^{\circ} \mathrm{C}$ & Zhang et al., \\
\hline & & Retro POL-B1 & GGCAATGAGAACGTCATCCATG & & psid & & 1996 \\
\hline 13 & TiLV & Nested ext-1 & TATGCAGTACTTTCCCTGCC & 491 & & $60^{\circ} \mathrm{C}$ & Eygnor et al., \\
\hline & & Nested ext-2 & TTGCTCTGAGCAAGAGTACC & & & & 2014 \\
\hline & & ME1 & GTTGGGCACAAGGCATCCTA & 250 & & & \\
\hline & & ME2 & TATCACGTGCGTACTCGTTCAGT & & & & \\
\hline 14 & VHSV & VHSV F & ATGGAAGGAGGAATTCGTGAAGCG & 505 & $\mathrm{~N}$-gene & $55^{\circ} \mathrm{C}$ & Snow et al., \\
\hline & & VHSV R & GCGGTGAAGTGCTGCAGTTCCC & & & & 2004 \\
\hline 15 & VNNV & BNV UF 1 & CAACTGACARCGAYCACACCTTCG & 570 & RNA 2 & $57^{\circ} \mathrm{C}$ & Gomez et al., \\
\hline & & BNV UR 1 & CGDGGYTGCKSRTCRGARTARTA & & segment & & 2004 \\
\hline & & BNV UF 2 & THCAAGCRACTCGYGGTGC & 420 & & & \\
\hline & & BNV UR 2 & TGCCARTAVACRGCMCGKTCVACRTC & & & & \\
\hline
\end{tabular}




\section{RNA Isolation, cDNA Synthesis and PCR Amplification}

RNA was extracted from tissue samples using TRI reagent (Sigma, St. Louis, MO, USA) following manufacturer's protocol followed by treatment with DNase I, RNase-free (Fermentas, Thermo Fisher Scientific, Wilmington, DE, USA) and inactivation of DNase I as per manufacturer's instructions. The concentration and purity of total RNA samples were quantified by measuring OD at $260 \mathrm{~nm}$ and checking the ratio of $O D$ at $260 \mathrm{~nm}$ and $280 \mathrm{~nm}$ using NanoDrop ND1000 spectrophotometer. The CDNA was synthesized from total RNA using Verso cDNA Synthesis kit (Thermo Scientific) according to the manufacturer's instructions. PCR amplification was performed for suspected fish viral pathogens using published oligonucleotide primers (Table 2) for eight freshwater finfish RNA viruses as described earlier.

\section{Sequencing and Phylogenetic Analysis}

The positive amplicons for CyHV-2, CEV and VNNV were purified using PureLink Quick Gel extraction kit (Invitrogen, Carlsbad, CA). Three positive samples from
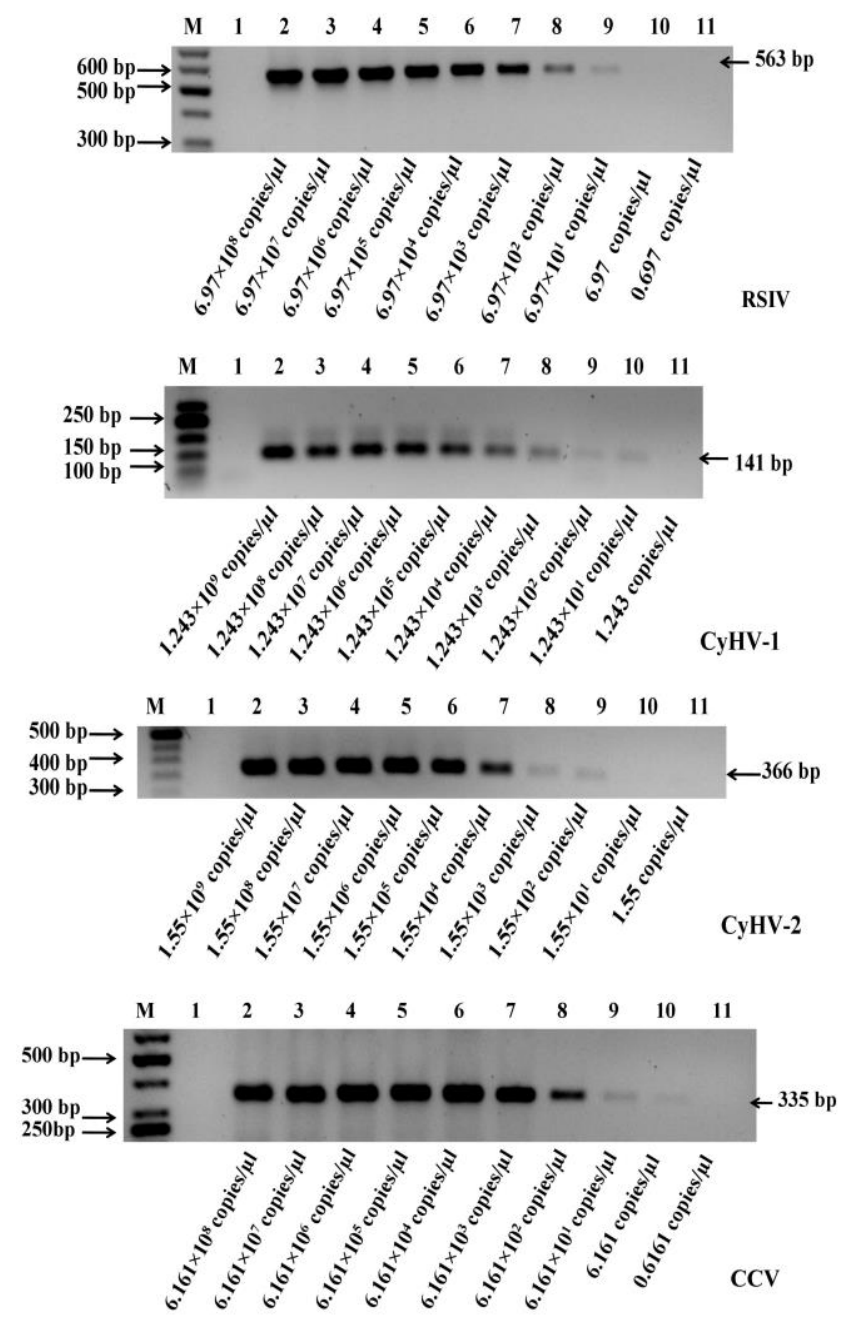

Figure 2. Semi-quantitative PCR for eight finfish viruses' viz., RSIV, GCRV, CyHV-1,VHSV, CyHV-2,VNNV,CCV, and MCV and their

diagnostic sensitivities (only to be used for virus screening). each state were sequenced commercially (AgriGenome Labs Pvt Ltd, Kochi, India). The nucleotide sequences were analysed using the Basic Local Alignment Search Tool (BLAST) of NCBI to find out the homology. Phylogenetic analysis of CEV 5'UTR gene, CyHV-2 helicase gene and VNNV RNA2 segment were constructed through neighbour-joining method of MEGA X (Saitou and Nei, 1987).

\section{Results}

\section{Standardization of Semi-Quantitative PCR-Based Diagnostics for Various Pathogens}

Respective cloned amplicons for positive controls were confirmed and BLAST analysis showed 100\% similarity with already available gene sequence for all of these eleven viruses that were undertaken in the current study. PCR amplification for diagnostic development of eleven freshwater fish viruses was performed (Figure 2). The sensitivities of different PCRs for these eleven different viruses were determined using semi-quantitative PCR. It was found to be 69.7 copies/ $\mu \mathrm{L}$ for RSIV, 12.43 copies/ $\mu \mathrm{L}$ for CyHV-1, 155
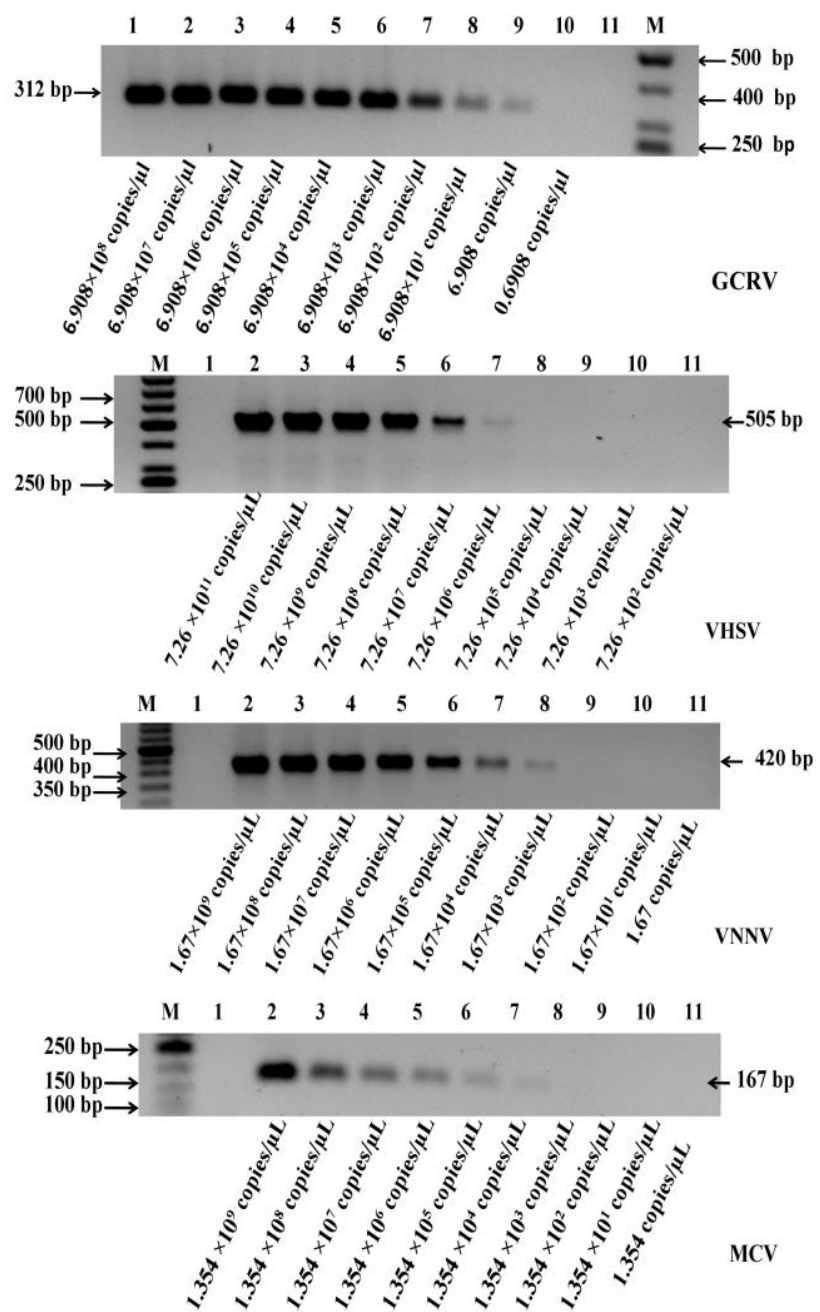
copies/ $\mu \mathrm{L}$ for CyHV-2, 6.907 copies/ $\mu \mathrm{L}$ for GCRV, 6.16 copies/ $\mu \mathrm{L}$ for $\mathrm{CCV}, 1.67 \times 10^{3}$ copies $/ \mu \mathrm{L}$ for $\mathrm{VNNV}$, $7.26 \times 10^{6}$ copies $/ \mu \mathrm{L}$ for VHSV, and $1.34 \times 10^{4}$ copies $/ \mu \mathrm{L}$ for Megalocytivirus-ISKNV.

\section{PCR Screening of Samples}

Tissue samples collected from fish were individually pooled and screened for seven DNA fish viruses and eight RNA viruses. Out of 271 samples screened for DNA viruses, samples were found to be negative for MCV, CyHV-1, CCV, LCDV, RSIV, and positive for CyHV-2 and CEV (Table 3) (Figures 3 \& 4). PCR amplification performed for 166 samples for eight fish RNA viruses revealed positive for VNN in nested PCR (Table 3, Figure 5). None of the samples collected from Assam state was found positive for any of the viruses studied here. The prevalence (\%) of CyHV-2, CEV and VNN in suspected samples was found to be 35.71, 27.86 and 17.91, respectively. It was observed that fishes from two orders namely Cypriniformes (Family: Cyprinidae, species: Carassius and Cyprinus) and Perciformes (Family: Latidae, species: Lates) out of total six orders were mostly affected with viral infections in the present study.

\section{Phylogenetic Analysis}

The positive amplicons obtained for both CyHV-2 and CEV were cloned and confirmed via sequencing. There was no change at the nucleotide level for the amplicons obtained for each of the positive samples sequenced between two geographically distinct regions. A BLAST search for these positive amplicons revealed 99.18\% and $98.79 \%$ identities with previously published helicase and 5'UTR gene sequences of CYHV-2 and CEV, respectively. Also, the nucleotide BLAST of the partial sequence of VNNV amplicon revealed $100 \%$ identity with Red spotted grouper nervous necrosis virus (RGNNV) genotype. Three phylogenetic trees based on partial nucleotide sequences of CyHV-2 helicase, CEV 5'UTR sequence and VNNV RNA2 gene segments were constructed (Figure 6). The isolate of CyHV-2 was being close to our previously identified West Bengal isolate, CEV was being close to KX503807 isolate of South Korean origin and VNNV isolate was similar to KC696562 RGNNV strain of Spain origin and previous reported betanodavirus strain from Kolkata (MG575047). More balanced topology was noticed for all three viruses in the phylogenetic tree.

\section{Discussion}

This paper presents a comprehensive and sample based-surveillance of freshwater fishes in three major states (Odisha, West Bengal and Assam) in India for virus detection. Out of all 437 PCR samples screened, the prevalence rate of $35.71 \%$ for CyHV-2, 27.86\% for CEV and $17.91 \%$ for VNNV was observed. All data on prevalence of these viruses rely on PCR detection followed by sequencing of representative samples. The cell line infectivity in first outbreak cases has already been reported, except for CEV due to lack of susceptible cell lines (Parameswaran et al., 2008; Sahoo et al., 2016). These three viruses were earlier being reported from India either from outbreak (in case of CyHV-2) or sporadic cases of mortalities from freshwater environments (Banu et al., 2019; Binesh et al., 2013; Sahoo et al., 2016, 2020a,b; Swaminathan et al., 2016). To our surprise, none of the samples were found to be positive for ISKNV or TiLV or ranavirus that are being noticed from India earlier (Anonymous, 2018; George et

Table 3. Result of samples screened for freshwater finfish viral pathogens

\begin{tabular}{llcc}
\hline S.No & Viruses screened & $\begin{array}{c}\text { Number of } \\
\text { samples screened }\end{array}$ & Result \\
\hline DNA viruses & 70 & $\begin{array}{c}\text { Positive (25 no.) } \\
\text { Negative }\end{array}$ \\
1 & Herpes viral haematopoietic necrosis (CyHV-2 virus) & 31 & Negative \\
2 & Megalocytivirus-ISKNV & 38 & Positive (17 no.) \\
3 & Cyprinid Herpesvirus 1 (CyHV-1) & 61 & Negative \\
4 & Carp Edema Virus (CEV) & 6 & Negative \\
5 & Channel Catfish Virus (CCV) & 23 & Negative \\
6 & Lymphocystivirus (LCDV) & 42 & 271 \\
7 & Red Sea Bream Iridovirus (RSIV) & & Negative \\
Total number of samples screened for DNA virus & & Negative \\
RNA viruses & 10 & Negative \\
1 & Viral Haemorrhagic Septicemia Virus (VHSV) & 20 & Negative \\
2 & Spring Viremia of Carp (SVCV) & 4 & Negative \\
3 & Walleye Dermal Sarcoma Virus (WDSV) & 4 & Negative \\
4 & Grass Carp Reo Virus (GCRV) & 28 & Negative \\
5 & Snakehead Rhabdovirus (SHRV) & 15 & Positive (12 no.) \\
6 & Tilapia Lake Virus (TiLV) & 18 & 166 \\
7 & Snakehead Retrovirus (SnRV) & 67 & 437 \\
8 & Viral Nervous Necrosis Virus (VNNV) & & \\
\hline
\end{tabular}




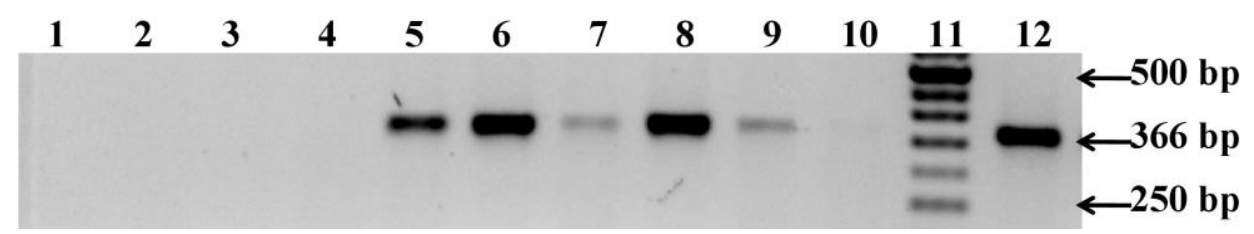

Figure 3. PCR amplification of helicase gene using primer CyHV-2 Hel F/R. Lane 1: PCR negative control, lanes 2-6 represent infected goldfish samples isolated from Odisha, lanes 7-10 represent goldfish sampled from West Bengal and lane 11: 50 bp molecular marker (StepUp, Genei). Lane 12: CyHV-2 positive control.

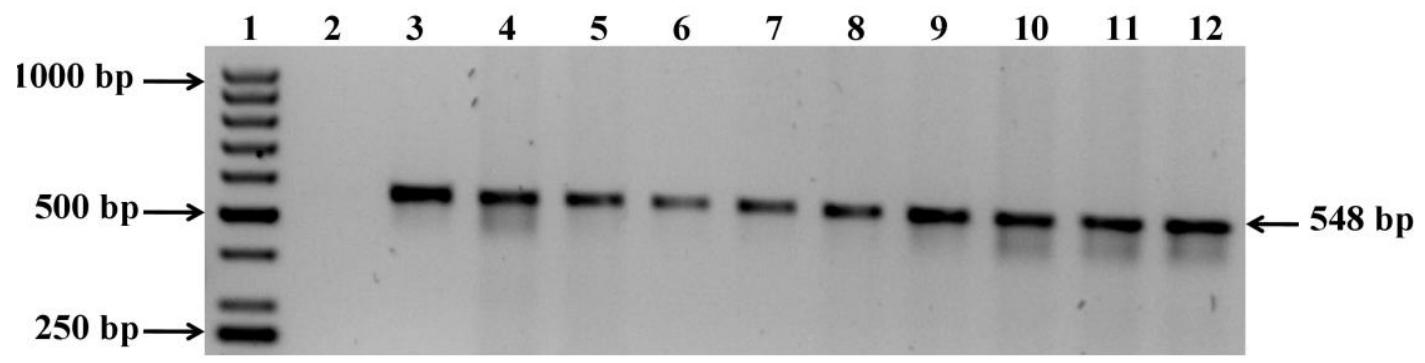

Figure 4. PCR amplification of 5' UTR gene of carp edema virus using CEV F1/R1 first step primers. Lane 1: 50 bp molecular marker (Thermo Scientific), lane 2: PCR negative control, lanes 3-8 represent koi carp suspected samples isolated from Odisha, lane 9-11 represent koi carp sample from West Bengal andlane 12: CEV positive control.

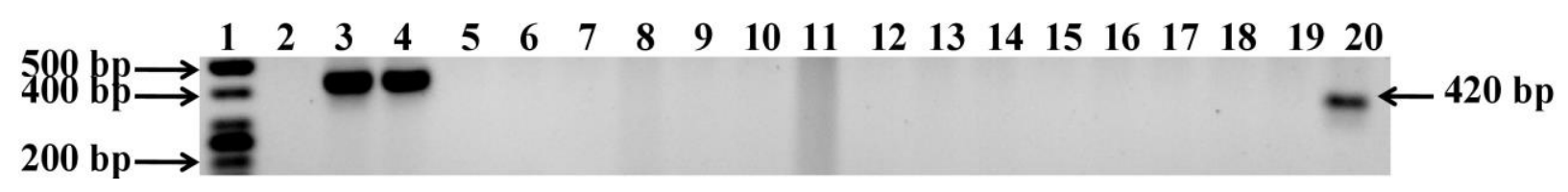

Figure 5. PCR amplification of VNNV RNA 2 segment with nested primer UF2/UR2. Lane 1: 50 bp molecular marker (Thermo scientific), lane 2: PCR negative control, lanes 3-19 represent pooled organs of individual seabass from West Bengal, and lane 20: VNNV positive control.

al., 2015; Behera et al., 2018). All the later three viruses were from single mortality events and these are not being reported thereafter from India. Hence, further indepth sampling or investigation is required about existence or spread of these three pathogens in studied area. However, the diagnostic sensitivity of the primer sets used for diagnosis of VHSV and ISKNV along with PCR conditions need to be further improved upon before drawing any conclusion for their absence.

CyHV-2 is a pathogen that was associated with goldfish, Prussian carp, and other species of the genus Carassius (Wei et al., 2019). Various cases of goldfish mortalities due to this virus have been reported across the globe including Japan, USA, UK, Australia, New Zealand, Taiwan, Hungary, Czech Republic, France, Italy, India and China (Sahoo et al., 2016; Wei et al., 2019). All the goldfish samples collected here were from nonclinical cases but tested positive using CyHV-2 helicase gene (Ouyang et al., 2019). This finding is in accordance with the studies reported by Wei et al. (2019) showing asymptomatic healthy goldfish survivors could also harbour CyHV-2 infections and be a potential source for covert infections in wild as well as in farms. CyHV-2 has become an emerging disease due to worldwide trade of asymptomatic healthy goldfishes and continues to be a major route of spread mostly because of absence of routine detection (Sahoo et al., 2016; Ito et al., 2017).

CEV was detected from both states of Odisha and West Bengal, and phylogeny tree revealed the amplicons were closer to the ones already reported from India earlier (Swaminathan et al., 2016; Sahoo et al., 2020a). Prevalence of $27.8 \%$ pointed towards the necessity of CEV surveillance all over the country and revealed presence of asymptomatic koi carps in aquarium being traded heavily and poses a threat to ornamental sector in India. The transportation and temperature stress factors aggravating the rate of incidences could not be ruled out.

The positive data from the nested PCR results of VNNV showed that betanodavirus being widespread in farms as well as in wild as a carrier. Prevalence of $17.9 \%$ from the state of West Bengal showed the persistence of this virus in stocks of Indian fishes. Earlier reports also revealed its presence in both marine as well as freshwater systems from various regions of India (Azad et al., 2005; Parameswaran et al., 2008; Jithendran et al., 2011; Binesh, 2013; Binesh et al., 2013; Banerjee et al., 2014; Banu et al., 2019). This study also supports our earlier hypothesis of latency or persistency of this virus in wild seeds, thus serving as a source of viral inoculum for spreading the infection in cultured seabass either in fresh or brackish water (Banu et al., 2019). Again, 
$\mathbf{A}$

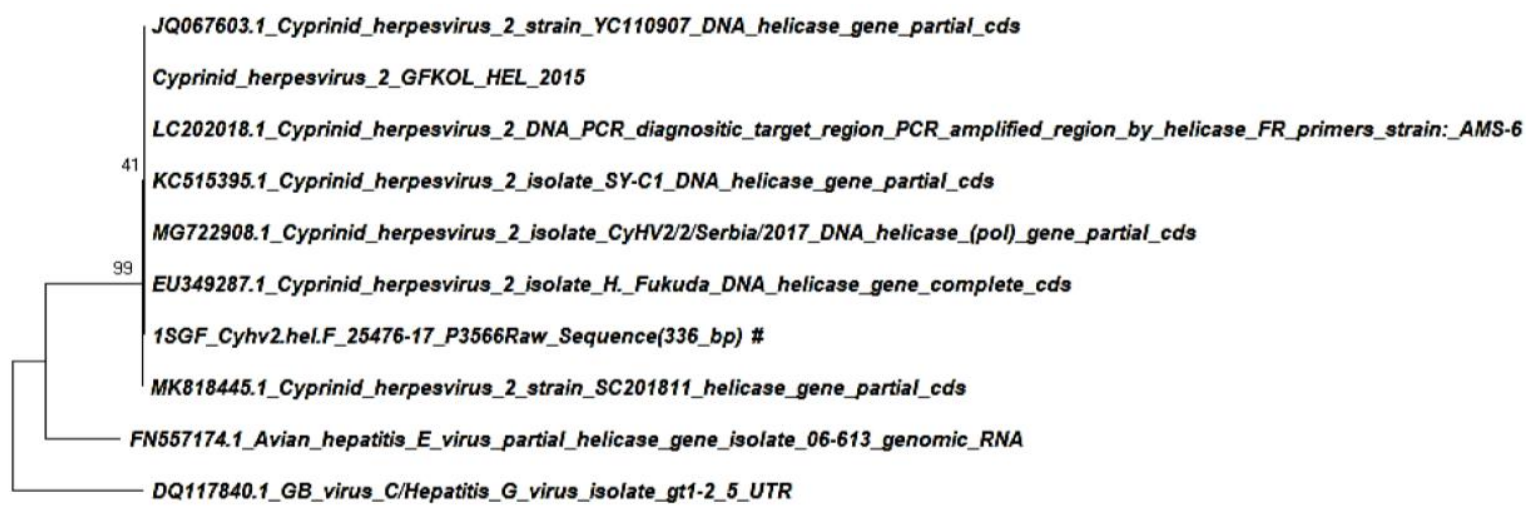

$\mapsto$

0.50

B

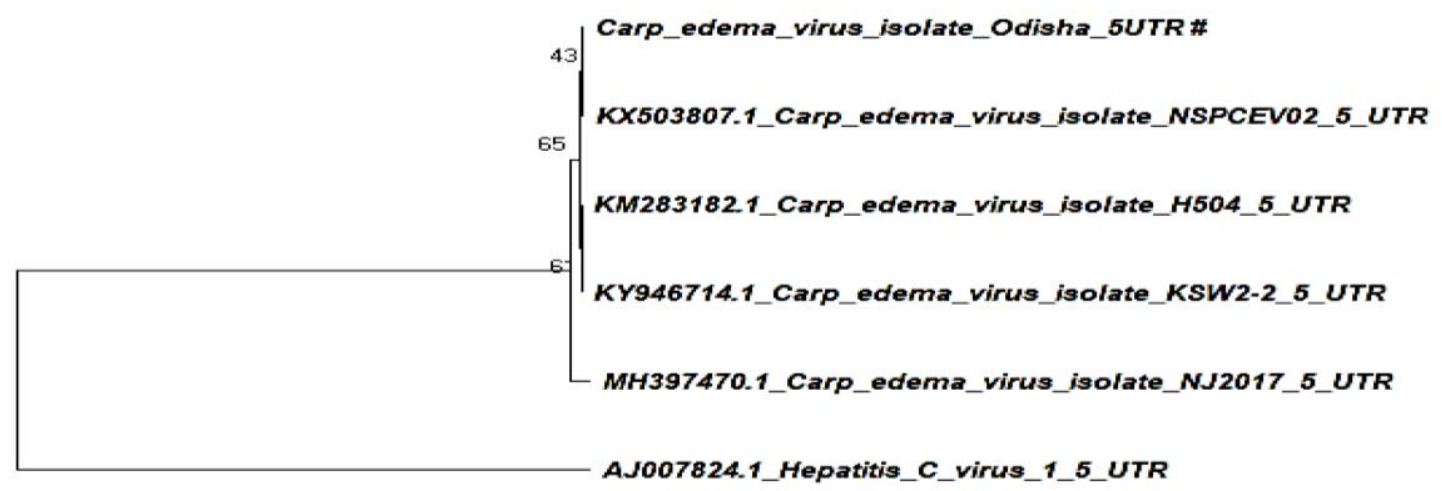

0.10

C 99 CU826138.1_Barfin_flounder_virus_BF93Hok_segment_RNA2_complete_sequence

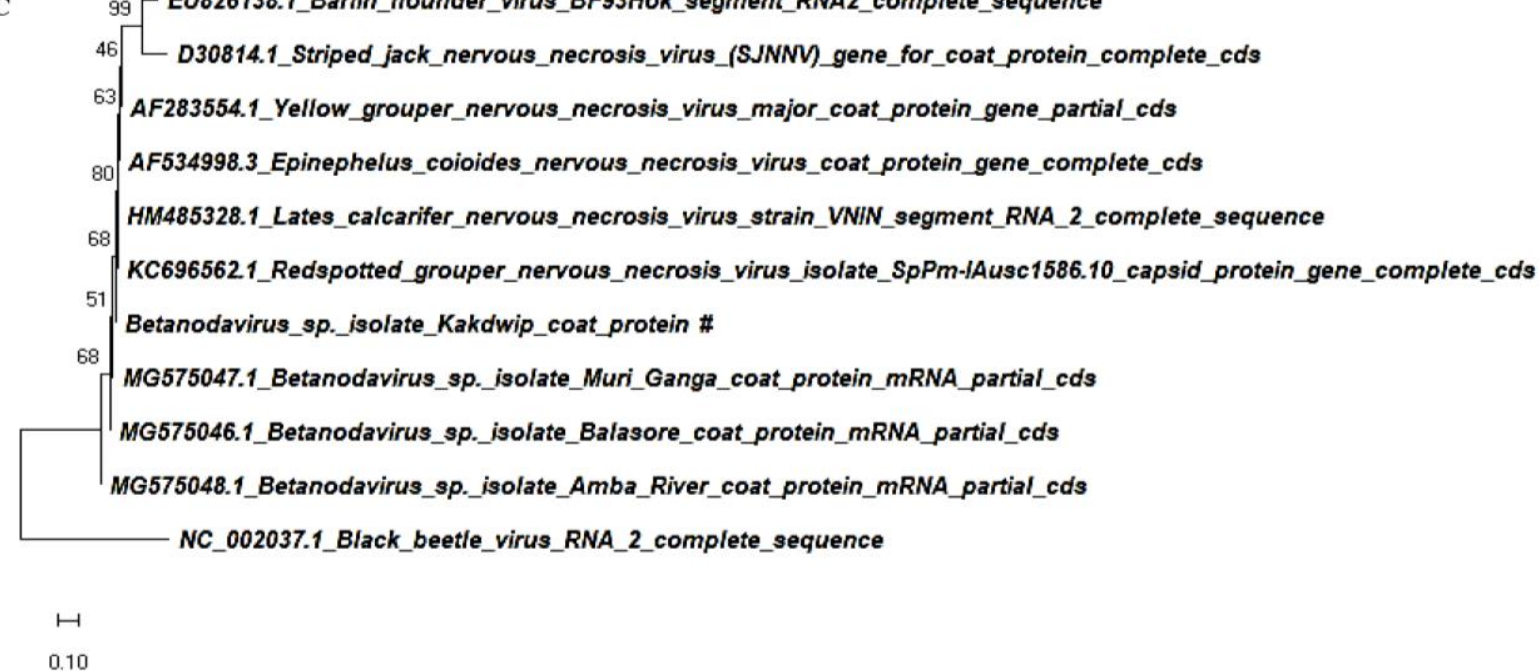

Figure 6. The evolutionary histories were inferred using the Neighbor-Joining method (Saitou and Nei, 1987). The percentage of replicate trees in which the associated taxa clustered together in the bootstrap test (500 replicates) is shown next to the branches (Felsenstein, 1985). The tree is drawn to scale, with branch lengths in the same units as those of the evolutionary distances used to interpret the phylogenetic tree. Maximum Composite Likelihood method (Tamura and Kumar, 2004) was used to compute evolutionary distances and are in the units of the number of base substitutions per site. Codon positions included were $1 \mathrm{st}+2 \mathrm{nd}+3 \mathrm{rd}+$ Noncoding. All ambiguous positions were removed for each sequence pair (pairwise deletion option). Evolutionary analyses were conducted in MEGA X (Kumar et al., 2018). A. CyHV-2 phylogenetic tree based on helicase nucleotide sequence. The optimal tree with the sum of branch length=2.29142355 is shown. This analysis involved 10 nucleotide sequences. There were a total of 1451 positions in the final dataset. B. CEV phylogenetic tree based on 5'UTR nucleotide sequence. The optimal tree with the sum of branch length $=1.25046251$ is shown. This analysis involved 6 nucleotide sequences. There were a total of 518 positions in the final dataset. C. VNNV based on RNA 2 segment nucleotide sequence. The optimal tree with the sum of branch length $=1.55471562$ is shown. This analysis involved 11 nucleotide sequences. There were a total of 1467 positions in the final dataset. 
RGNNV seems to be dominant genotype of VNN present in India. However, it is not possible to conclude whether the RNA detection represented a persistent viral production with possible intermittent shedding, as true latent or dormant infections are mostly not known to occur for RNA viruses.

Further, the study highlights the importance of rendering protection to native cultured fish by preventing their introduction and chance of spreading on local or national scale to either known or unknown susceptible fish species available in the region. The study also supports requirement of strong surveillance to prevent further mortality or economic loss due to these pathogens. The absence of other viruses also warrants strict vigilance on their entry to this region.

\section{Ethical Statement}

The research sample was moribund or apparently sick fish which were collected from farms following Institute ethical committee guidelines and clearance. The fish samples were collected after euthanizing with overdose of anaesthesia, MS222 (Sigma-Aldrich, USA).

\section{Funding Support}

$\begin{aligned} & \text { Funding support from } \\ & \text { Biotechnology, } \\ & \text { Govt. }\end{aligned}$ of of India
(BT/PR12660/AAQ/3/710/2014) is duly acknowledged.

\section{Authors Contribution}

V.B.: Investigation, Writing-Original Draft; D.P.: Investigation, Writing - Original Draft, J.M.: Writing -Review \& Editing, Supervision, Validation; P.K.S.: Conceptualization, Methodology, WritingReview \& Editing, Supervision, Validation, Project administration, Funding acquisition, Resources.

\section{Conflicts of Interest}

There is no conflict of interests involved in this manuscript.

\section{References}

Anonymous (2018). Megalocytivirus infection in ornamental fish CIFA News, 4, 5.

Azad, I.S., Shekhar, M.S., Thirunavukkarasu, A.R., Poornima, M., Kailasam, M., Rajan, J.J.S., \& Ravichandran, P. (2005). Nodavirus infection causes mortalities in hatchery produced larvae of Lates calcarifer: first report from India. Diseases of Aquatic Organisms, 63(2-3), 113-118. https://doi.org/10.3354/dao063113.

Banerjee, D., Hamod, M.A., Suresh, T., \& Karunasagar, I. (2014). Isolation and characterization of a nodavirus associated with mass mortality in Asian seabass (Lates calcarifer) from the west coast of India. Virus Disease, 25(4), 425-429. https://doi.org/10.1007/s13337-014-0226-8.

Banu, H., Pattanayak, S., Sundaray, J.K., \& Sahoo, P.K. (2019). Genetic diversity and latency status of betanodavirus in wild seeds of Asian seabass Lates calcarifer (Bloch) sampled along Indian coasts. Indian Journal of Geo-Marine Sciences, 48(3), 288-293.

http://nopr.niscair.res.in/handle/123456789/47050

Behera, B.K., Pradhan, P.K., Swaminathan, T.R., Sood, N., Paria, P., Das, A., \& Parida, P.K. (2018). Emergence of tilapia lake virus associated with mortalities of farmed Nile tilapia Oreochromis niloticus (Linnaeus 1758) in India. Aquaculture, 484, 168-174. https://doi.org/10.1016/j.aquaculture.2017.11.025.

Binesh, C.P. (2013). Mortality due to viral nervous necrosis in zebrafish Danio rerio and goldfish Carassius auratus. Diseases of Aquatic Organisms, 104(3), 257-260. https://doi.org/10.3354/dao02605.

Binesh, C.P., Renuka, K., Malaichami, N., \& Greeshma, C. (2013). First report of viral nervous necrosis-induced mass mortality in hatchery-reared larvae of clownfish, Amphiprion sebae Bleeker. Journal of Fish Diseases, 36(12), 1017-1020. https://doi.org/10.1111/jfd.12001.

Brown, S.P., Cornforth, D.M., \& Mideo, N. (2012). Evolution of virulence in opportunistic pathogens: generalism, plasticity, and control. Trends in Microbiology, 20(7), 336-342. https://doi.org/10.1016/j.tim.2012.04.005

Crane, M., \& Hyatt, A. (2011). Viruses of fish: An overview of significant pathogens. Viruses, 3, 2025-2046. https://doi.org/10.3390/v3112025

Enkeleda, B, \& Spase, S. (2014). First detection of spring viremia of carpvirus in Cyprinus carpio, in lake Shkodra/Scadar Albania. International Journal of Innovative Research in Science, Engineering and Technology, 3(12), 18170-18175. 10.15680/IJIRSET.2014.0312058, www.ijirset.com

Felsenstein, J. (1985). Confidence limits on phylogenies: An approach using the bootstrap. Evolution, 39,783-791. https://doi.org/10.1111/j.1558-5646.1985.tb00420.x

Garseth, A.H., Moldal, T., Gasnes, S.K., Hjortaas, M.J., Sollien, V.P., \& Gjevre, A.G. (2019). Piscine orthoreovirus-3 is prevalent in wild seatrout (Salmo trutta L.) in Norway. Journal of Fish Diseases, 42(3), 391-396.

https://doi.org/10.1111/jfd.12943

George, M.R., John, K.R., Mansoor, M.M., Saravanakumar, R., Sundar, P., \& Pradeep, V. (2015). Isolation and characterization of a ranavirus from koi Cyprinus carpio L., experiencing mass mortalities in India. Journal of Fish Diseases, 38, 389-403. https://doi.org/10.1111/jfd.12246

Gomez, D.K., Sato, J., Mushiake, K., Isshiki, T., Okinaka, Y., \& Nakai, T. (2004). PCR-based detection of betanodaviruses from cultured and wild marine fish with no clinical signs. Journal of Fish Diseases, 27(10), 603608.https://doi.org/10.1111/j.1365-2761.2004.00577.x

Gray, W.L., Williams, R.J., \& Griffin, B.R. (1999). Detection of channel catfish virus DNA in acutely infected channel catfish, Ictalurus punctatus (Rafinesque), using the polymerase chain reaction. Journal of Fish Diseases, 22(2), 111-116. https://doi.org/10.1046/j.1365-2761.1999.00155.x

Ito, T., Kurita, J., \& Haenen, O. L. M. (2017). Importation of CyHV2-infected goldfish into the Netherlands. Diseases of Aquatic Organisms, 126, 51-62. https://doi.org/10.3354/dao03157.

Jeong, J.B., Cho, H.J., Jun, L.J., Hong, S.H., Chung, J.K., \& Do Jeong, H. (2008). Transmission of iridovirus from freshwater ornamental fish (pearl gourami) to marine fish (rock bream). Diseases of Aquatic Organisms, 82(1), 27-36. https://doi.org/10.3354/dao01961

Jiang, Y. (2009). Hemorrhagic disease of grass carp: status of outbreaks, diagnosis, surveillance, and research. The Israeli Journal of Aquaculture, 61(3), 188-197. http://www.siamb.org.il/articles-1180-The-Israeli-Journalof-Aquaculture-Bamidgeh-(IJA). aspx 
Jithendran, K.P., Shekhar, M.S., Kannappan, S., \& Azad, I.S. (2011). Nodavirus infection in freshwater ornamental fishes in India: diagnostic histopathology and nested RT-PCR. Asian Fisheries Science, 24, 12-19.

https://www.researchgate.net/publication/320166253

Ke, G. M., Cheng, H. L., Ke, L. Y., Ji, W. T., Chulu, J. L., Liao, M. H., \& Liu, H. J. (2006). Development of a quantitative light cycler real-time RTPCR for detection of avian reovirus. Journal of Virological Methods, 133(1), 6-13. https://doi.org/10.1016/j.jviromet.2005.09.011

Kitamura, S.I., Jung, S.J., \& Oh, M.J. (2006). Differentiation of lymphocystis disease virus genotype by multiplex PCR. The Journal of Microbiology, 44(2), 248-253. https://www.researchgate.net/publication/7053647

Kumar S., Stecher G., Li M., Knyaz C., \& Tamura, K. (2018). MEGA $X$ : Molecular Evolutionary Genetics Analysis across computing platforms. Molecular Biology and Evolution, 35, 1547-1549. doi: 10.1093/molbev/msy096.

Kurita, J., \& Nakajima, K. (2012). Megalocytiviruses. Viruses, 4(4), 521-538. https://doi.org/10.3390/v4040521

Kurita, J., Nakajima, Z., Hirono, I., \& Aoki, T. (1988). Polymerase chain reaction (PCR) amplification of DNA of 'red sea bream iridovirus (RSIV). Fish Pathology, 33(1), 17-23. https://doi.org/10.3147/jsfp.33.17

Matras, M., Borzym, E., Stone, D., Way, K., Stachnik, M., MajPaluch, J., Palusińska, M., \& Reichert, M. (2017). Carp edema virus in Polish aquaculture-evidence of significant sequence divergence and a new lineage in common carp Cyprinus carpio (L.). Journal of Fish Diseases, 40(3), 319-325. https://doi.org/10.1111/jfd.12518

Ouyang, P., Zhou, Y., Wang, K., Geng, Y., Lai, W., Huang, X., ... Tang, L. (2020). First report of Cyprinid herpesvirus 2 outbreak in cultured gibel carp, Carassius auratus gibelio at low temperature. Journal of the World Aquaculture Society, 51, 1208-1220. https://doi.org/10.1111/jwas.12681

Oyamatsu, T., Matoyama, H., Yamamoto, K., \& Fukuda, H. (1997). A trial for detection of carp edema virus by using polymerase chain reaction. Aquaculture Science 45,247251. https://doi.org/10.11233/aquaculturesci1953.45.247

Parameswaran, V., Kumar, S.R., Ahmed, V.I., \& Hameed, A.S. (2008). A fish nodavirus associated with mass mortality in hatchery-reared Asian seabass Lates calcarifer. Aquaculture. 275(1-4), 366-369. https://doi.org/10.1016/j.aquaculture.2008.01.023

Phelan, P.E., Pressley, M.E., Witten, P.E., Mellon, M.T., Blake, S., \& Kim, C.H. (2005). Characterization of snakehead rhabdovirus infection in zebrafish (Danio rerio). Journal of Virology, 79(3), 1842-1852.

https://doi.org/10.1128/jvi.79.3.1842-1852.2005

Pragyan, D., Bajpai, V., Suman, K., Mohanty, J., \& Sahoo, P.K. (2019). A review of current understanding on carp edema virus (CEV): A threatful entity in disguise. International Journal of Fisheries and Aquatic Studies, 7(5), 87-93.

Rimmer, A.E., Becker, J.A., Tweedie, A., \& Whittington, R.J. (2012). Development of a quantitative polymerase chain reaction (qPCR) assay for the detection of dwarf gourami iridovirus (DGIV) and other megalocytiviruses and comparison with the Office International des Epizooties (OIE) reference PCR protocol. Aquaculture, 358, 155-163. https://doi.org/10.1016/j.aquaculture.2012.06.034

Sahoo, P.K., \& Goodwin, A.E. (2012). Viruses of freshwater finfish in the Asia-Pacific region. Indian Journal of Virology, 23, 99105. https://doi.org/10.1007/s13337-012-0102-3
Sahoo, P.K., Swaminathan, T.R., Abraham, T.J., Kumar, R., Pattanayak, S., Mohapatra, A. \& Pradhan, P.K. (2016). Detection of goldfish haematopoietic necrosis herpes virus (Cyprinid herpesvirus-2) with multi-drug resistant Aeromonas hydrophila infection in goldfish: First evidence of any viral disease outbreak in ornamental freshwater aquaculture farms in India. Acta Tropica, 161, 8-17. https://doi.org/10.1016/j.actatropica.2016.05.004

Sahoo, P.K., Pattanayak, S., Paul, A., Sahoo, M.K. \& Kumar, P.K. (2020a). Carp edema virus in ornamental fish farming in India: A potential threat to koi carps but no to co-cultured Indian major carp or goldfish. Indian Journal of Experimental Biology, 58, 254-262.

http://nopr.niscair.res.in/handle/123456789/54260

Sahoo, P.K., Paul, A., Sahoo, M.K., Pattanayak, S., Rajesh Kumar P. \& Das, B.K. (2020b). Incidences of infectious diseases in freshwater aquaculture farms of eastern India: A passive surveillance based study from 2014-2018. Journal of Aquaculture Research and Development, 11, 579. doi: 10.35248/2155-9546.20.10.579

Saitou N., \& Nei, M. (1987). The neighbor-joining method: A new method for reconstructing phylogenetic trees. Molecular Biology and Evolution, 4, 406-425.

https://doi.org/10.1093/oxfordjournals.molbev.a040454

Snow, M., Bain, N., Black, J., Taupin, V., Cunningham, C.O., Skall, H.F., \& Raynard, R.S. (2004). Genetic population structure of marine viral haemorrhagic septicaemia virus (VHSV). Diseases of Aquatic Organisms, 61(1-2), 11-21. https://doi.org/10.3354/dao061011

Swaminathan, T.R., Kumar, R., Dharmaratnam, A., Basheer, V.S., Sood, N., Pradhan, P.K., \& Jena, J.K. (2016). Emergence of carp edema virus in cultured ornamental koi carp, Cyprinus carpio koi, in India. Journal of General Virology, 97(12), 3392-3399. https://doi.org/10.1099/jgv.0.000649

Tamura, K., Nei, M., \& Kumar, S. (2004). Prospects for inferring very large phylogenies by using the neighbor-joining method. Proceedings of the National Academy of Sciences (USA) 101, 11030-11035. https://doi.org/10.1073/pnas.0404206101

Viadanna, P.H., Miller-Morgan, T., Peterson, T., Way, K., Stone, D.M., Marty, G.D., ... Waltzek, T.B. (2017). Development of a PCR assay to detect cyprinid herpesvirus 1 in koi and common carp. Diseases of Aquatic Organisms, 123(1), 1927. https://doi.org/10.3354/dao03066

Walker, P.J., \& Winton, J.R. (2010). Emerging viral diseases of fish and shrimp. Veterinary Research, 41, 51. https://doi.org/10.1051/vetres/2010022

Waltzek, T.B., Kurobe, T., Goodwin, A.E., \& Hedrick, R.P. (2009). Development of a polymerase chain reaction assay to detect cyprinid herpesvirus 2 in goldfish. Journal of Aquatic Animal Health, 21(1), 60-67. https://doi.org/10.1577/h08-045.1

Wei, C., lida, H., Chuah, Q., Tanaka, M., Kato, G., \& Sano, M. (2019). Persistence of cyprinid herpesvirus 2 in asymptomatic goldfish Carassius auratus (L.) that survived an experimental infection. Journal of Fish Diseases, 42(6), 913-921. https://doi.org/10.1111/jfd.12996

Zhang, Z., Du Tremblay, D., Lang, B.F., \& Martineau, D. (1996). Phylogenetic and epidemiologic analysis of the walleye dermal sarcoma virus. Virology, 225(2), 406-412. https://doi.org/10.1006/viro.1996.0616 